This is an early draft of the paper which eventually appears as http://www.tandfonline.com/doi/full/10.1080/17439884.2016.11139

91. I can't upload the final version here because of copyright but I might be able to share an author version if you get in touch...

\title{
Open education and critical pedagogy
}

\author{
Dr. Robert Farrow \\ Institute of Educational Technology \\ The Open University \\ Walton Hall \\ Milton Keynes \\ MK7 6AA \\ rob.farrow@open.ac.uk
}

Submitted to special issue of Learning, Media \& Technology

(http://explore.tandfonline.com/cfp/ed/call-for-papers/cjem-cfp-feb-14)

Keywords: open education, OER, MOOC, critique, evidence, critical theory, critical pedagogy, discourse analysis, openwashing

Abstract: This paper argues for a revaluation of the potential of open education to support more critical forms of pedagogy. Section I examines contemporary discourses around open education, offering a commentary on the perception of openness as both a disruptive force in education, and a potential solution to contemporary challenges. Section II examines the implications of the lack of consensus around what it means to be open, focusing on the example of commercial and proprietary claims to openness commonly known as 'openwashing'. Section III uses Raymond's influential essay on open source software 'The Cathedral and the Bazaar' as a framework for thinking through these issues, and about alternative power structures in open education. In Section IV an explicit link is drawn between more equal or democratic power structures and the possibility for developing pedagogies which are critical and reflexive, providing examples which show how certain interpretations of openness can raise opportunities to support critical approaches to pedagogy. 


\section{Introduction}

This paper explores some of the under-theorised aspects of open education, primarily focusing on the possibilities for aligning openness in education with possibilities for what, following Freire (1970) and Kincheloe (2008), I term 'critical pedagogy'. Critical pedagogy represents a synthesis of educational theory and critical theory, taking from the latter an interest in the fundamental relations of power that influence the social order and the formation of human subjectivity. Critical pedagogues aim to encourage independently minded learners who question the status quo and engage explicitly with questions of truth, power and justice. Ira Shor (1992:129) has defined critical pedagogy as follows:

\footnotetext{
"Habits of thought, reading, writing, and speaking which go beneath surface meaning, first impressions, dominant myths, official pronouncements, traditional clichés, received wisdom, and mere opinions, to understand the deep meaning, root causes, social context, ideology, and personal consequences of any action, event, object, process, organization, experience, text, subject matter, policy, mass media, or discourse."
}

I shall argue below that this ongoing critical interest in forms of knowledge production and how they influence beliefs, thoughts and actions both in the individual and in society as a whole is characteristic of critical pedagogy, and that open education - and open educational resources (OER) in particular offers strategies that are conducive to such goals viz-à-viz improved understanding of both the conditions and techniques that support knowledge creation and transmission; and a sense of the importance of power relations for the pedagogical process itself. 
The rise of interest in open education - often in the form of Massively Open Online Courses (MOOC) - has been widely described as a radical or disruptive force which calls into question some basic assumptions about modern education. As John Daniels has written:

\begin{abstract}
"Open education broke open the iron triangle of access, cost and quality that had constrained education throughout history and had created the insidious assumption, still prevalent today, that in education you cannot have quality without exclusivity." (Daniels, cited in Wilson \& McCarthy, 2012).
\end{abstract}

The changes that are only just beginning to be felt all ultimately result from the fact that it is now easier than ever to produce and distribute educational media and resources. While this may have uncomfortable implications for educational institutions and commercial organisations that have an interest in controlling the supply of such resources, the potential for a more collective and inclusive approach to learning is considerable.

\title{
I. Openness and Discourses of Disruption
}

In these discourses surrounding MOOC reference to crisis in traditional education are more common and more hyperbolic. As Deimann (2015) has shown, discourse analysis of the media coverage of MOOC reveals of kind of neoliberal framing which portrays MOOC as an intervention which can open up new markets for education while revolutionizing existing ones. In particular, articles in the New York Times between 2012 and 2013 which support public 
investment in the 'efficiencies' of the private sector are identified closely with this framework. Narratives like these tend to promote the idea that technological innovation can offer a neat solution to the various problems that beset educational institutions.

Few would deny that contemporary institutions of higher education face a range of challenges. Against the backdrop of a general commodification of education and educational institutions, pedagogical relationships are changing and moving into uncharted waters. Students are increasingly viewed (and view themselves) as consumers and many see education as little more than preparation for the world of work rather than the traditional public good. Faculty are witnessing a bifurcation of their teaching and research roles which is now becoming entrenched the way that universities are run with many thousands of adjunct faculty on short zero hours contracts, lacking adequate employment security. In the USA and the UK levels of student debt continue to rise exponentially while the perceived value of a degree (especially in the arts and humanities) is falling. The fundamental value proposition of higher education is changing. In his recent book, The Battle for Open, Martin Weller summarizes this as follows:

Spending on education has been increasing, while the return graduates receive in terms of increased salary has been diminishing. In short, higher education is no longer a good return on investment from a purely monetary perspective. (Weller, 2014:94)

People are increasingly turning to open materials to meet their learning needs, and finding that there is a greater range of choice available than ever before, 
much of it available for free. At the same time, openness is increasingly proposed as a solution within formal educational institutions. Whether a crisis of funding, organization, accessibility, curriculum pedagogy, or resources there's an open, networked approach that has been suggested to address the problem. Broadly, these include moving to OER models of pedagogy, starting a MOOC, or increasing the provision of free digital resources. Open access publication, for instance, is intended to overcome restricted access to peer reviewed scholarship and research. Open licensing of textual and multimedia content as OER are upheld as a response to copyright laws which limit access to educational materials, raise the cost of education and stultify innovation in pedagogical practice. Open textbooks are presented as a solution to proprietary textbooks which are often prohibitively expensive in the USA (Senack, 2015).

Of the different elements within the constellation of 'open eduation', MOOCs have perhaps made greatest inroads into the popular imagination, with many inches of column space devoted to it in both academia and the popular press. The cheerleaders of the MOOC movement - who are themselves primarily providers of MOOC platforms like Coursera, EdX, Udacity, etc. - often portray their interventions as both practical solution to everyday problems and as a sort of historically necessary, technologically-necessary form of disruptive intervention. Apocalypse and crisis are thus motifs that are increasingly common in contemporary discourse around educational and media technology.

These approaches are often accompanied by the idea of some sort of salvation through technology and rooted in Christiansen's (1997) notion of disruptive 
innovation. In 2013, Christiansen - a professor in the Harvard Business School is reputed to have said the following:

Fifteen years from now more than half of the universities will be in bankruptcy, including the state schools. In the end, I am excited to see that happen. (Christiansen, quoted in Meisenhelder, 2013:8)

Similarly, Sebastian Thrun, founder of Udacity, has asserted that "In 50 years there will be only ten institutions in the whole world that deliver higher education" (quoted in Leckhart, 2012). With the "death" of one kind of practice, new practices better suited to context can emerge - or so the disruptive innovators would have it. Watters (2013) argues that that these apocalyptic myths have a pervasive effect in American culture, and that the idea of disruptive innovation is particularly prevalent among Silicon Valley entrepreneurs and in business. The ideologically saturated narrative leads to predictions about the inevitable decline of established systems in higher education: the move to mass online learning; the inevitable death of under-performing schools; a fundamental change in the nature of the university. Public institutions, it is argued, are unable to innovate because they are monolithically inflexible and somehow beyond the reach of the efficiency of market forces. We are encouraged to embrace forprofit and MOOC style education since their prevalence is seen as both economically necessary and as the inevitable culmination of the history of the academy and the future of professional training (Bond, 2013).

The New York Times (Pappano, 2012) went as far as to proclaim 2012 "The year of the MOOC" in anticipation of the far-reaching change that openness in education would bring about. Yet MOOC are increasingly weathered by 
skepticism and these narratives are being challenged. In 2012 the Babson

Survey Research Group added questions about MOOC to their annual survey of more than 2,800 chief academic officers in colleges and universities and found that most faculty and academic officers were in fact skeptical about the value of MOOC activity for their institution (Allen \& Seaman, 2013). The University of New England has gone as far as to completely cease its MOOC activity because it has been unable to monetize it successfully (Dodd, 2014a) while John Mitchell, vice-provost for online learning and overseer of Stanford's MOOC programme, has suggested that no college or university will be able to continue funding free courses without finding a way to cover the costs.

MOOCs have started out as a free opportunity - and free is a great way to get people interested... but traditionally, students in the US pay tuition to go to college or university and I don't think it is unreasonable to ask people to pay a little bit for education activities that help them to move forward in their careers... I think [Stanford] will have low cost, high volume, but non-free courses online that will help make our online programmes sustainable. (Quoted in Parr, 2014).

Commercial providers and university managers see in MOOC the potential profitability of scale and the promise of extending influence and reach without significantly increasing overheads. Though no-one has yet shown a viable business model from MOOC, major providers like edX have announced that they will begin charging for professional education courses from this year (Dodd, 2014b).

Questions are also being raised about the extent to which MOOC enhance access to education. Many predicted that MOOC would improve access to learning by 
removing economic and geographical barriers (a claim that has been made about technology-enhanced mass education since at least the 1950s). In particular, the claim that MOOC significantly increase access to education by extending opportunity to those demographics which are less represented in formal education systems has been shown to be highly problematic when most MOOC learners tend to be white, relatively wealthy, and most likely already in possession of (at least) an undergraduate degree (Laurillard, 2014; Emmanuel, 2013; Perryman, 2013).

With MOOC and their various derivatives, 'open' tends to be used to denote courses which can be joined by anyone who has the right technology to access content delivered online - there are no requirements in terms of prior qualification. This has led to some courses with many hundreds of thousands of registered learners, with an average enrollment of around 40,000 students (Jordan, 2014). MOOC have often described as either 'cMOOC' or 'XMOOC'. cMOOC originally ran to test Connectivist theories about networked learning through processes of accumulation, collective content creation, and sharing (Siemens, 2005). Most very large course numbers - sometimes with hundreds of thousands of learners - are found in the XMOOC, which typically make institutional course content available to very large numbers of learners but have been accused of being pedagogically retrograde (Stacey, 2014). As Bayne \& Ross (2014:21-22) note, we are starting to see a move away from the cMOOC/xMOOC binary and greater recognition of more diverse forms of open online course, including DOCC (Distributed Open Collaborative Course); POOC (Participatory 
Open Online Course); BOOC (Big/Boutique Open Online Course); and even a nonopen variant - SPOC (Small Private Online Course).

As the range of open approaches continues to diversify, it can be difficult to retain clarity about the 'open' dimension which is both distinctive and held in common. With a recognised lack of clear data about the impact of different open approches - especially with respect to informal, extra-institutional use of OER it can be difficult to effectively strategise open practices.

This lack of clear data - partly reflective of the informal and extra-institutional nature of much open learning - creates a space that allows for conjecture, divergent claims and hyperbole. But in essence these dichotomies reflect differing views about the meaning and value of openness in education.

\section{Competing Visions of 'Open'}

Does "open" mean openly licensed content or code? And, again, which license is really "open"? Does "open" mean "made public"? Does "open" mean shared? Does "open" mean "accessible"? Accessible how? To whom? Does "open" mean editable? Negotiable? Does "open" mean "free"? Does "open" mean "openended"? Does "open" mean transparent? Does "open" mean "openminded"? "Open" to new ideas and to intellectual exchange? Open to interpretation? Does "open" mean open to participation - by everyone equally? (Watters, 2014)

The act of attempting to define openness is itself valuable for the action, reflection and strategization of the open education movement. The language of openness is certainly used widely, and yet relatively little is known about the impact of openness on the learner. Yet, at the same time, openness retains an 
appeal for many. One way of accounting for this is through this very ambiguity, which is amenable to several interpretations, not all of which are necessarily consistent.

Because much use of OER is informal or undertaken to supplement formal study, identifying the specific influence of openness can be difficult. The open nature of OER introduces further intricacy into the complexities of pedagogical research. In part, this reflects the immature research context and lack of consistency in identifying and measuring open education. Many different definitions of openness in education have been proffered. For instance, as Cobo (2013) notes, openness of educational resources is typically characterized by three key features:

- Open intellectual property licences

- Permissions to duplicate/use/adapt/edit content in ways other than established by traditional copyright

- Non-discriminatory privilege (rights extend to any potential author)

This does not, however, translate into a shared understanding of what is meant or implied by 'openness' in practice. For example, it omits any reference to open technologies, methods of delivery, or practice - features which one might just as easily claim are essential aspects of open practice. In the context of a MOOC, for instance, 'open' typically refers to the removal of institutional or technological barriers to accessing educational content: like fees; physical location; entry requirements, and so on. In the context of OER, 'open' is typically used to refer to the licenses associated with or applied to a particular piece of content. Often the 
difficulties around precisely defining openness circulate around subtle contextual differences and the manifold ways openness can be interpreted. The clearest example of contested interpretations of openness can be found in the controversies around branding of proprietary content as 'open' without showing a clear commitment to the values of the open education movement.

The old 'open' vs. 'proprietary' debate is over and open won. As IT infrastructure moves to the cloud, openness is not just a priority for source code but for standards and APIs as well. Almost every vendor in the IT market now wants to position its products as 'open'. Vendors that don't have an open source product instead emphasize having a product that 'uses open standards' or has an 'open API'. (Finley, 2011)

It's telling that openness is now viewed as a marketing asset, but commercial publishers who describe their products as open when they are not licensed in such a way as to promote non-commercial re-use have been roundly criticized from within the open education movement. Wiley (2011) and others have termed this "openwashing" after the "greenwashing" phenomenon associated with the attempt by corporations to rebrand themselves as environmentally friendly as the green movement began to gain wider popularity (Jermier, 2013). Examples of publishers or elearning providers who have been criticized for branding their commercial products in this way include Pearson's 'OpenClass' learning management system, Udacity's 'Open Education Alliance', and the 'Open English' startup (Watters, 2014); as well as 'OpenEd Solutions' (Wiley, 2011). The stakes are believed to be high. As Weller (2014: 21) puts it: "This is not a polite debate about definitions... there will be very real consequences for education and society in general". For many in the open education movement 
the attempt to commercialise the concept of open is seen as an affront on their efforts.

Commentators like Peters \& Deimann (2013:13) have consequently suggested there is a need to differentiate 'pure' (authentic) openness towards 'pretended' (inauthentic) openness which offers a justification of more control for producers and other commercial stakeholders. As Weller (2011:105) notes, the original statement of the Open Course Ware approach was to act as an alternative system of course material delivery in a time when content providers sought ever more control over the protection and exploitation of their intellectual property. So openness in the first instance can be seen as arising from the attempt to liberate educational materials from the restrictions placed on them by copyright holders like elearning providers and publishers.

Arguably, the lack of consensus about what should qualify as legitimately 'open' has its roots in the flexibility and undetermined nature of the concept.

Few words in the English language pack as much ambiguity and sexiness as 'open'... Profiting from the term's ambiguity [from] the 'openness' of open source software to the 'openness' of the academic enterprise, markets and free speech. (Morozov, 2013)

When we refer to openness we tend to refer to some field of possible action rather than a set of licensing options or some other criteria. The most open licensing options are also the least restrictive in terms of prescribing the behavior of others; as Wiley (2014) notes, any restrictions on use increase the 'friction' involved in working with open content. Openness has a close 
association with freedom - giving permissions to join a course, to remix resources, to read a journal, and so on - and arguing that commercial providers must adopt certain licences or practices is anathema to this core element of openness.

My suggestion will be that we should think in terms of multiple forms of openness rather than making judgements about whether a particular resource or practice qualifies as 'open' on the basis of a binary quality like having a particular licence. Our starting point for reflecting on this are of the two forms of organization identified in Eric Raymond's ruminations on the value of top-down and bottom-up models of design in software production, 'The Cathedral and the Bazaar' (Raymond, 2000). My suggestion will be that we may outline two models for thinking about authenticity and openness that are differentiated by their underlying power structures, and illustrate the ways in which the 'bazaar' offers more potential for reflexivity and critique. (However, it should not be inferred from this that we should categorize open interventions according to another dualistic or binary framework: my intention is rather to provide a preliminary distinction which can support further reflection without being reductive.)

\section{The Cathedral and Bazaar Revisited}

In Raymond's (2000) essay, the 'cathedral' and 'bazaar' refer to two different approaches to software development which can be extrapolated out to social 
organization and design. The 'cathedral' model emphasizes top-down, 'reverent' design, where code is shared between a small group of skilled developers who co-create something complicated. Essentially, the cathedral model uses a closed group of experts to produce a complex product, much like the medieval artisans and guild members who worked to construct and decorate the great cathedrals. By contrast, the 'bazaar' model involves developing code in the open via public, online forum. By developing code in the open it becomes available for scrutiny, criticism and potential redevelopment from a wide range of developers at different levels of skill. Raymond proposes that the more widely available source code is made, the more efficient the process of debugging becomes. The relative openness of the public space of the 'bazaar' allows for more dispersed patterns of collective intelligence while the 'cathedral' sets out a grand vision or plan and then works towards realizing this through the use of experts. Severance (2010) has offered some further characteristics of the 'bazaar' approach, including use of open licensing; transparency of processes and decisions; horizontal power structures; lack of institutional control; and voluntary cooperation as a central organizing principle. The more authentically 'open' nature of the bazaar is identified with more widely dispersed models of power, and with a striving towards a collective consensus about the best method of action.

Thinking about the different kinds of provision that have been made in open education, we can extend this analogy further. The major MOOC providers which present mass online education as the next step in the evolution of educational technology may be thought of as cathedral builders, experts working to create grand edifices which will shape the subjects of future. Of course, we shouldn't 
think of all MOOC as fitting this model - 'Connectivism and Connective Knowledge' (Downes, 2012) the original MOOC by George Siemens and Stephen Downes embodied a dynamism and reflexivity that identifies it more closely with the 'bazaar' model - but the larger MOOC providers are often effectively institutions involved in delivery of a grand design whose operations tend to emphasize vertical power and an asymmetrical model of communication and coordination. Arguably this is more closely associated with xMOOC, though within the spectrum of cMOOC (Connectivist or Constructivist MOOC) we can find instances which are closer to either model. In short, the 'bazaar' offers the possibility for more autonomous, spontaneous forms of knowledge redistribution and collaboration, while the 'cathedral' approach places the focus on the architectonic, the grand design which requires a significant (top-down) co-ordination of effort in order to be realized. The 'cathedral' approach sees in open education the potential for rolling out educational provision to large audiences, and in practice ultimately seeks a financial return which reflects the extent of the investment made. Higher education institutions involved in producing and releasing open content through MOOC are in the process of building the educational systems of the future and this requires a degree of organization that the relative anarchy of the bazaar might struggle to provide. The 'bazaar' is instead geared towards a more 'do-it-yourself' approach where actors produce and consume the open content that is relevant to their own needs as educators and/or learners. 
Thus we may differentiate two broad approaches to open education (independent of commercial interest) without superficially identifying these directly with inauthentic and authentic expressions of openness respectively. Though both approaches deserve to be called authentically open in their respective ways, arguably the 'bazaar' approach allows for a greater degree of personal autonomy as a result of more horizontal structures of power and influence. We see this most clearly in the case of OER which are produced and used informally or locally, or tailored to very specific or even individual need; what has been termed 'little' OER (Weller, 2010). The 'bazaar' is decentralized perhaps messier and noisier - but also offers greater opportunity for personal freedom, agency, expression and engagement for a larger number of subjects.

\section{Open education and critical pedagogy}

This essay began with the observation that some commentators have identified MOOC with the expression of neoliberal reform in higher education. This position can be understood to draw together a number of different objections to open education, and reflects a general shift in the academy from humanistic values and methods towards rationalization, efficiency, industrialization, and commercialization. There is certainly a temptation to view innovations of open education in this way when mass education at marginal cost offers the promise of replacing what is not provided by the state. But, as I have suggested, much of this perspective can be attributed to some of the hype around MOOC, much of it originating from those with a vested interest in the 'disruption' narrative. It 
would (of course) be erroneous to categorise all MOOC in this way but it remains the case that for the more high-profile providers the liberation of course content and the liberalization of higher education markets goes hand-in-hand. This aspect of 'open' appears to enable neoliberal aspects as a result of the centralization of administration, assessment and accreditation, and since most major MOOC providers are businesses rather than universities they also contribute to the corporatization of knowledge.

Though clearly important, an adequate discussion of these issues would take us beyond the ambitions of the present paper. Instead, I will concentrate in this final section on opportunities for autonomy, reflexivity and critical pedagogy offered where open education is aligned to the 'bazaar' model of production rather than the relatively didactic approaches found in XMOOC provision.

Feenberg (2002, Ch. 5) has noted that critical approaches are often excluded from debates around educational technologies, and it's reasonable to state that the relationship between technology and critical theory is generally undertheorized. Critical approaches to knowledge production recognize that knowledge is fundamentally political and bound up with distinctively human interests (Habermas, 1971). Critical approaches to education thus strive towards emancipatory forms of knowledge; i.e. those that illuminate or deconstruct the economic and social circumstances within which a particular piece of knowledge is produced and understood. 
Critical pedagogy, in contrast to traditional pedagogy, understands authentic education as fundamentally emancipatory. There are many interconnected theoretical frameworks which appeal to this notion, including critical realism (Corson, 1991; Emami and Riordan,1998; Shipway, 2004); critical theorists in the French (Foucault, 1986) and German (Kellner, 2003; Gur-Ze'ev, 2005) traditions and the well-known bodies of work in pedagogy and psychology by Freire (1970), Illich (1971) and Dewey (1938; 1995). Despite various differences of emphasis, what unites these approaches to education is the interest in the critique of oppressive or dominant economic and/or sociopolitical force in education, and focus explicitly on how this shapes traditional educational processes and techniques. Core to these approaches is the idea that learners must recognise the contested nature of knowledge through an understanding of its production and validation. Clearly, educational and media technologies have come to play a central role in mediating these understandings. Construed as mediating technologies, OER and MOOC can be seen to democratize in different ways: MOOC in terms of access to educational resources and OER in terms of the production and use of educational resources.

One reason to think that OER can support critical pedagogies is through the greater autonomy they afford educators and learners in choosing educational materials from a more diverse user base. Through the creation, adaptation and localization of educational resources we can facilitate new ways of perceiving, categorizing, mapping, and connecting the relationship between theory and practice (OER Research Hub, 2014). By opening up the processes of generation and use of educational resources to a greater variety of actors a culture of 
interrogating (and improving) pedagogical techniques can be encouraged.

Within education systems that emphasize the value of copyrighted content OER should be thought of as potentially radical agents of change (McAndrew \& Farrow, 2012:74). Open licensing of a resource enables a range of behaviours or 'open educational practices' (Conole, 2011) - that encourage a new kind of relationship toward the materials created that is arguably more reflective of authentic, situated needs.

Objections usually raised to the idea of democratizing educational processes (rather than democratizing access to formal education) draw on the importance of expert knowledge for effective pedagogy and may assume that OER are of inferior quality to proprietary materials. Such worries are usually overstated, especially as the open education movement has established clearer guidelines and co-ordination around quality standards and evaluation. But it is perhaps worth bearing in mind Freire's (1970:9) suggestion that "[l]iberating education consists in acts of cognition, not transferals of information". Concerns about the quality of a particular resource are valid, but may overlook the fact that there are already a plethora of alternative resources available in any given area. More crucial is the need to pose and solve problems since it is through this process that that learners better come to understand their own reality. We need learners to feel more confident and in control of their choices about their own learning, and recognising that learners will inevitably seek out resources and so should be encouraged to develop their own sense of critical media literacy. But the relative anarchy of the bazaar is also to be celebrated in its own right for the culture of self-reliance and critical autonomy that can be fostered. 
As Richard Shaull wrote in his foreword to Freire's Pedagogy of the Oppressed, education is always already politicised, concerned with the formation of future subjects and establishing normative expectations around practices of conformity and freedom:

Education either functions as an instrument which is used to facilitate integration of the younger generation into the logic of the present system and bring about conformity or it becomes the practice of freedom, the means by which men and women deal critically and creatively with reality and discover how to participate in the transformation of their world. (Freire, 1970:34)

Undoubtedly, more research is needed into the kind of support we need to offer the learners of a future world where information is in abundance, and there remain critical questions around the right kind of media and critical literacies that should be developed. However, depending on the interpretation of 'openness' being offered, it is possible to be understand both as a bulwark against - and a potential pathway for - neo-liberal reforms in education. As I have noted above, more clarity is needed in the terminology employed around openness so as to make it easier to distinguish different use cases and the degrees of openness made possible by particular platform or technology. The most open forms of licensing - rarely used in the more commercially minded MOOC models - increase the capacity for adapting, reusing and remixing materials. By doing this they increase the potential for engagement with educational resources, promoting critical reflection on the resources and the 
circumstances under which they have been produced. This can be as a result of purely pedagogical focus (such as in the case of an educator who selects and adapts resources to more closely fit classroom needs) but can also reflect the new kinds of communicative practices that are developing around OER and the communities that make and use them.

It is the decentralization and democratization of control over knowledge production and pedagogy afforded by open licensing that is key to appreciating the potential afforded by OER to critical pedagogy. Of course, MOOC do enable a kind of educational dialogue which, depending on the kind of MOOC involved, may afford greater or lesser opportunities for critique. For instance, there are already indications of the adoption of critical perspectives within open education, including MOOC based on the principles of critical pedagogy which articulate the pedagogical value of openness through new kinds of dialogic space and encourage the uptake of critical perspectives.

Several examples of approaches which can be seen to fit the approach outlined can be identified. The highly innovative course DS106 (Digital Storytelling 106) is a course offered for credit at The University of Mary Washington but which is also open for enrolment from anyone online. Students can join or leave at any time, and assessments and course assignments - generally based on using digital media creatively - are designed collaboratively then used by future students (Stacey, 2014:113). DS106 fosters the agency and creativity of all participants through equalizing access to both course content and pedagogical design, and by 
inviting students to rethink processes of assessment a critical attitude towards is encouraged.

Another example may be found in Saylor Academy (2015) who are providers of more than 100 open textbooks and structured content which map to undergraduate curriculum. They have taken the unusual step of adding their content to GitHub, a repository which allows users to clone and adapt content while preserving the originals through version control. By moving from proprietary document formats to pure HTML shared in this way they have found a technical solution which supports wider contributions and facilitates collaboration. This approach shows that further democratizing the process of open textbook production need not lead to sacrificing quality. Furthermore, the invitation to critique learning resources written by experts encourages the uptake of critical perspectives.

Connectivist MOOC have long been interested in developing the autonomy and self-reliance of participants. Several experimental cMOOC have taken direct inspiration from the work of critical pedagogues and designing courses that emphasize learner agency over and above the epistemological authority of course instructors. The 'MOOC MOOC' series of MOOC by Sean Michael Morris and Jesse Stommel which use open and critical methods to investigate MOOC themselves place critical pedagogy at the forefront of their approach. The course was designed to encourage participants to question the very proposition of a MOOC and how it operates through a largely discursive, improvised approach to 
reflection, disaggregated across a range of social media. Reflecting on the outcomes of these courses, the course instructors write:

The pedagogical value in openness is that it can create dialogue, and can deconstruct the teacher-student binary, by increasing access and bringing together at once disparate learning spaces. Openness can function as a form of resistance both within and outside the walls of institutions. But open education is no panacea. Hierarchies must be dismantled - and that dismantling made into part of the process of education - if its potentials are to be realized (Morris \& Stommel, 2014).

\section{Conclusion}

The best kind of openness acts as a challenge to traditional educational practice and so opens up a reflective space for thinking and doing otherwise. I have argued that the 'bazaar' model of open education is more democratic, encourages more active participation, and can act as a catalyst for reflection on (and critique of) the pedagogical process.

At this point in human history more people have more access to better educational resources at any point in the past. This should be a cause for optimism! But it also means more research is needed into the kind of support we need to offer the learners of the future in a world where information is ubiquitous and content more readily available to educators and learners than ever before. 
Crucially, openness is becoming a more important category in education, and thus one where something important for the future is at stake (as we saw with the controversies around 'openwashing'). In the different interpretations of openness in education that currently exist we can determine a number of potential futures. Some of these are more like what we have now, others are more different, and there are dystopian and utopian versions of all of them. What is most important at this stage is for relevant parties to continue to engage around the theme of openness, think about the ways in which openness can make a difference to individual or group practice, and to remain optimistic about things moving in the right direction.

Critical approaches to education have "a normative and even utopian dimension, attempting to theorize how education and life construct alternatives to what is." (Kellner, 2003:3). By democratizing the processes through which educational materials and processes are designed and delivered, open education allows a greater plurality of voices to be heard and to contribute, and the experiences of groups who are often marginalized may be better heard: perhaps this is what we should really mean by 'open'. 


\section{References}

Allen, E. \& Seaman, J. (2013). Changing Course: Ten Years of Tracking Online Education in the United States. Babson Survey Research Group and Quahog Research Group, LLC. Available from http://www.onlinelearningsurvey.com/reports/changingcourse.pdf. Accessed $5^{\text {th }}$ May 2015.

Atkins, D., Seely Brown, J., \& Hammond, A. L. (2007). A review of the open educational resources (OER) movement: Achievements, challenges, and new opportunities. San Francisco, CA: William and Flora Hewlett Foundation. http://www.hewlett.

org/uploads/files/ReviewoftheOERMovement.pdf. Accessed 5th May 2015.

Bayne, S. \& Ross, J. (2014). The pedagogy of the Massive Open Online Course: the UK view. The Higher Education Academy. Available from

https://www.heacademy.ac.uk/sites/default/files/HEA_Edinburgh_MOOC_WEB_240314_1.pdf. Accessed $5^{\text {th }}$ May 2015.

Bond, P. (2013). Massive Open Online Courses (MO0C) for Professional Development and Growth. In Smallwood, C., Harrod, K. \& Gubnitskaia, V. (eds.) Continuing Education for Librarians. Jefferson: McFarland and Company.

Cape Town Declaration on Open Education (2007). Available from http://www.capetowndeclaration.org/. Accessed 5th May 2015.

Christian, C. (1997). The Innovator's Dilemma: When New Technologies Cause Great Firms to Fail. Harvard Business Press.

Cobo, C. (2013). Exploration of Open Educational Resources in Non-English Speaking Communities. International Review of Research in Open and Distance Learning Vol. 15, No. 2. Available from http://www.irrodl.org/index.php/irrodl/article/view/1493/2482. Accessed 5th May 2015.

Corson, D. (1991). Bhaskar's Critical Realism and Educational Knowledge. British Journal of Sociology of Education. Vol. 12, No. 2 pp. 223-241.

Creative Commons (2013). What is OER? Available from http://wiki.creativecommons.org/What_is_OER\%3F. Accessed 5th May 2015.

Deimann, M. (2015). The dark side of the MOOC: A critical inquiry on their claims and realities. Current Issues in Emerging eLearning. Vol. 2, Issue 1, Article 3. Available from http://scholarworks.umb.edu/ciee/vol2/iss1/3/. Accessed 5 ${ }^{\text {th }}$ May 2015.

Dewey, J. (1938). Experience \& Education. New York, NY: Kappa Delta Pi.

Dewey, J. (1995) [1916]. Democracy and Education. New York: The Free Press.

Dodd, T. (2014a). UNE shuts down its loss-making MOOCs. Australian Financial Review. 25th August 2014. Available from:

http://www.afr.com/p/national/education/une_shuts_down_its_loss_making_moocs_ZQoeYL6tu cYL6h5TJTAXBI. Accessed 5 ${ }^{\text {th }}$ May 2015.

Dodd, T. (2014b). Top MOOC provider edX no longer free for all. Australian Financial Review. $6^{\text {th }}$ October 2014. Available from

http://www.afr.com/p/national/education/top_mooc_provider_edx_no_longer_FooMSmV3LdSQ HYGKND4LoI. Accessed 5th May 2015.

Downes, S. (2012). Connectivism and Connective Knowledge. Available from http://www.downes.ca/post/58207. Accessed 5th May 2015.

Emami, Z., \& Riordan, T. (1998). Tony Lawson on Critical Realism: What's Teaching Got to Do With It? Review of Social Economy, 56(3), 311-323. 
Emmanuel, E. J. (2013). Online Education: MOOCs taken by educated few. Nature 503, 342. doi:10.1038/503342a

Feenberg, A. (2002). Transforming Technology: A Critical Theory Revisited. Oxford University Press.

Finley, K. (2011). How to Spot Openwashing. ReadWrite.com. http://readwrite.com/2011/02/03/how_to_spot_openwashing. Accessed 5th May 2015.

Foucault, M. (1986) [1975]. Discipline and Punish: The Birth of the Prison. Harmondsworth: Peregrine.

Friere, P. (1970). Pedagogy of the Oppressed. New York: Continuum Books.

Friesen, N. (2008). Critical Theory: Ideology Critique and the Myths of E-Learning. Ubiquity (June). Available from http://ubiquity.acm.org/issue.cfm?volume=2008\&issue=June. Accessed $5^{\text {th }}$ May 2015.

Gur-Ze'ev (ed.) (2005). Critical Theory and Critical Pedagogy Today: Toward a New Critical Language in Education. Haifa, Israel: University of Haifa Press.

Habermas, J. (1971). Knowledge and Human Interests. trans. by Jeremy J. Shapiro. Boston: Beacon Press.

Habermas, J. (1989)[1962]. The Structural Transformation of the Public Sphere. T. Burger and F. Lawrence (trans). Cambridge, MA: MIT Press.

Illich, I. (1971) Deschooling Society. New York: Harper and Row.

Jermier, J. M. (ed.) (2013). Corporate Environmentalism and the Greening of Organizations. SAGE Library in Business and Management.

Jordan, K. (2014). Initial trends in enrolment and completion of massive open online courses. The International Review of Research In Open And Distributed Learning, 15(1). Available from http://www.irrodl.org/index.php/irrodl/article/view/1651. Accessed 5th May 2015.

Kellner, D. (2003). Towards a critical theory of education. Available from http://pages.gseis.ucla.edu/faculty/kellner/papers/edCT2003.htm.

Kincheloe, J. L. (2008). Critical Pedagogy (2nd Ed.). New York: Peter Lang Publishing.

Knox, J. (2013) Five Critiques of the Open Educational Resources Movement. Teaching in Higher Education, Vol.18 Issue 8. Available from http://www.tandfonline.com/doi/pdf/10.1080/13562517.2013.774354. Accessed 5th May 2015.

Laurillard, D. (2014). What is the problem for which MOOCs are the solution? ALT Online Newsletter (June 26 ${ }^{\text {th}}$ ) https://newsletter.alt.ac.uk/2014/06/what-is-the-problem-for-whichmoocs-are-the-solution/. Accessed $5^{\text {th }}$ May 2015.

Leckhart, S. (2012). The Stanford Education Experiment Could Change Higher Learning Forever. Wired. Available from http://www.wired.com/2012/03/ff_aiclass/. Accessed 5th May 2015.

McAndrew, P. \& Farrow, R. (2013). 'Open Education Research: From the Practical to the Theoretical' in McGreal, R., Kinuthia, W. and Marshall, S. (eds) Open Educational Resources: Innovation, Research and Practice. Commonwealth of Learning and Athabasca University, Vancouver. pp.65-78. Available from https://oerknowledgecloud.org/sites/oerknowledgecloud.org/files/pub_PS_OER-IRP_CH5.pdf. Accessed $5^{\text {th }}$ May 2015. 
Meisenhelder, S. (2013). MOOC Mania. The NEA Higher Education Journal. Fall 2013. Available from http://www.ww.isea.org/assets/docs/HE/TA2013Meisenhelder.pdf. Accessed 5 ${ }^{\text {th }}$ May 2015.

Morris, S. M. \& Stommel, J. (2014). If Freire Made a MOOC: Open Education as Resistance. Open Education 2014. Open Education 2014. Hilton Crystal City, Arlington, Virginia, USA. Available from http://www.hybridpedagogy.com/tag/OpenEd/. Accessed 5th May 2015.

Mozorov, E. (2013). The Meme Hustler. The Baffler No. 22. Available from http://www.thebaffler.com/articles/the-meme-hustler. Accessed 5 $5^{\text {th }}$ May 2015.

Nichols, R., \& Allen-Brown, V. (1996). Critical theory and educational technology. In D. Jonassen (Ed.), Handbook of research for educational communications and technology. New York: Simon and Shuster Macmillan, 226-252.

OER Research Hub (2014). OER Policy Map. Available from http://oermap.org/policy-map/. Accessed $5^{\text {th }}$ May 2015.

Pappano, L. (2012). The Year of the Mooc. New York Times. Available from http://www.nytimes.com/2012/11/04/education/edlife/massive-open-online-courses-aremultiplying-at-a-rapid-pace.html?pagewanted=all\&_r=0. Accessed $5^{\text {th }}$ May 2015.

Parr, C. (2014). Moocs are free - but for how much longer? Times Higher Education, $21^{\text {st }}$ August. Available from http://www.timeshighereducation.co.uk/news/moocs-are-free-but-for-howmuch-longer/2015204.article. Accessed 5th May 2015.

Perryman, L.-A. (2013). Can OER break down barriers to participation in education? OER Research Hub. http://oerresearchhub.org/2013/08/16/can-oer-break-down-barriers-toparticipation-in-education/. Accessed $5^{\text {th }}$ May 2015.

Peter, S., \& Deimann, M. (2013). On the role of openness in education: A historical reconstruction. Open Praxis, 5(1), 7-14. doi:10.5944/openpraxis.5.1.23

Raymond, E. S. (2000). The Cathedral and the Bazaar. http://www.catb.org/ esr/writings/cathedral-bazaar/cathedral-bazaar/index.html. Accessed $5^{\text {th }}$ May 2015.

Saylor Academy (2015). Saylor Academy hosted textbooks now in HTML and editable by anybody. Available from http://www.saylor.org/2015/03/blog-saylor-academy-hostedtextbooks-now-in-html-and-editable-by-anybody/. Accessed $5^{\text {th }}$ May 2015.

Senack, E. (2015). Open Textbooks: The Billion-Dollar Solution. Student PIRGS. Available from http://www.studentpirgs.org/reports/sp/open-textbooks-billion-dollar-solution. Accessed $5^{\text {th }}$ May 2015.

Severance, C. (2010). Considering Open - Rethinking Cathedral and Bazaar. Dr. Chuck's Blog. http://www.dr-chuck.com/csev-blog/2010/01/considering-open-rethinking-cathedral-andbazaar/. Accessed $5^{\text {th }}$ May 2015.

Shipway, B. (2004). The Educational Limits of Critical Realism? Emancipation and Rational Agency in the Compulsory Years of Schooling. 2004 IACR Conference (Cambridge, UK). Available from http://www.csog.group.cam.ac.uk/iacr/papers/Shipway.pdf. Accessed $5^{\text {th }}$ May 2015.

Shor, I. (1992). Empowering Education: Critical Teaching for Social Change. University of Chicago Press.

Siemens, G. (2005). Connectivism: A learning theory for the digital age. International Journal of Instructional Technology and Distance Learning, 2(1), 3-10.

Smith, M.S. \& Casserly, C.M., (2006). The promise of open educational resources. Change: The Magazine of Higher Learning, 38(5), 8-17. 
Stacey, P. (2014). Pedagogy of MOOCs. INNOQUAL - International Journal for Innovation and Quality in Learning. Vol. 2, No. 3. Available from

http://www.papers.efquel.org/index.php/innoqual/article/view/161/50. Accessed $5^{\text {th }}$ May 2015.

Thomson, S. (2010). Unicycle Open Educational Resources Project Report. JISC. Available from https://oerknowledgecloud.org/sites/oerknowledgecloud.org/files/unicycle_final_report.pdf. Accessed $5^{\text {th }}$ May 2015.

Tonks, D., Weston, S., Wiley, D., \& Barbour, M. (2013). “Opening” a new kind of school: The story of the Open High School of Utah. The International Review Of Research In Open And Distance Learning, 14(1), 255-271. Available

from http://www.irrodl.org/index.php/irrodl/article/view/1345/2419. Accessed 5th May 2015.

Watters, A. (2014). From "Open" to Justice \#OpenCon2014. Hack Education. Available from http://hackeducation.com/2014/11/16/from-open-to-justice/. Accessed $5^{\text {th }}$ May 2015.

Weller, M. (2010). Big and little OER. In: OpenED2010: Seventh Annual Open Education Conference, 2-4 November 2010, Barcelona, Spain. Available from http://oro.open.ac.uk/24702/. Accessed $5^{\text {th }}$ May 2015.

Weller, M. (2014). Battle for Open: How openness won and why it doesn't feel like victory. London: Ubiquity Press. DOI: http://dx.doi.org/10.5334/bam.

Wiley, D. (2011). Openwashing - the new greenwashing. iterating towards openness. http://opencontent.org/blog/archives/1934. Accessed 5th May 2015.

Wiley, D. (2014). Refining the Definition of “Open” in Open Content. iterating towards openness. http://opencontent.org/blog/archives/3442. Accessed 5th May 2015.

Wilson, A. \& McCarthy, R. (2012). "The Future of (Open) Education with Sir John Daniel."

Education Policy and Reform Unit, UNESCO Bangkok. Available from

http://www.unescobkk.org/news/article/the-future-of-open-education-with-sir-john-daniel/. Accessed $5^{\text {th }}$ May 2015. 